\title{
Nutritional adequacy of three dietary patterns defined by cluster analysis in 997 pregnant Japanese women: the Osaka Maternal and Child Health Study
}

\author{
Hitomi Okubo 1,2,*, Yoshihiro Miyake ${ }^{3}$, Satoshi Sasaki 1,4, Keiko Tanaka ${ }^{3}$, \\ Kentaro Murakami ${ }^{4}$, Yoshio Hirota ${ }^{5}$ and Osaka Maternal and Child Health Study Group \\ 'Department of Social and Preventive Epidemiology, Graduate School of Medicine, The University of Tokyo, \\ Hongo 7-3-1, Bunkyo-ku, Tokyo 113-0033, Japan: ${ }^{2}$ Research Fellow of the Japan Society for the Promotion of \\ Science, Japan: ${ }^{3}$ Faculty of Medicine, Department of Public Health, Fukuoka University, Fukuoka, Japan: \\ ${ }^{4}$ Department of Social and Preventive Epidemiology, School of Public Health, The University of Tokyo, Tokyo, \\ Japan: ${ }^{5}$ Department of Public Health, Osaka City University Graduate School of Medicine, Osaka, Japan
}

Submitted 24 March 2010: Accepted 9 July 2010: First published online 21 September 2010

\begin{abstract}
Objective: To examine the adequacy and inadequacy of dietary patterns in pregnant women for which information is absolutely lacking.

Design: Diet was assessed by a validated, self-administered diet history questionnaire (DHQ). Dietary patterns were extracted from the intake of thirty-three food groups (g/4184 kJ (1000 kcal)), which were summarized from 147 foods assessed with the DHQ, by cluster analysis. Nutritional inadequacy for selected twenty nutrients in each dietary pattern was examined using the reference values given in the Dietary Reference Intakes (DRI) for Japanese as the temporal gold standard.

Setting: Japan.

Subjects: Nine hundred and ninety-seven pregnant Japanese women aged 18-43 years. Results: The three dietary patterns identified were labelled as 'meat and eggs' ( $n$ 423), 'wheat products' ( $n$ 371) and 'rice, fish and vegetables' ( $n$ 203). The 'rice, fish and vegetables' pattern characterized by high intake of rice, vegetables, potatoes, pulses, fruits, seaweed, fish and miso soup showed significantly the lowest prevalence of inadequate intake for fifteen nutrients and significantly the highest prevalence of inadequate sodium intake. In contrast, the 'wheat products' pattern characterized by high intake of bread, noodles, confectioneries and soft drinks showed the highest prevalence of inadequate intake for fourteen nutrients. The median number of nutrients not meeting the DRI as a marker of overall nutritional inadequacy was eight in the 'rice, fish and vegetables' pattern. It was significantly lower at ten in the 'meat and eggs' and eleven in the 'wheat products' patterns $(P<0 \cdot 001)$.

Conclusions: In pregnant Japanese women, the dietary pattern high in rice, fish, vegetables, fruit and some others showed a better profile of nutritional adequacy except for sodium.
\end{abstract}

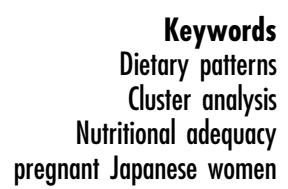

Dietary patterns

Cluster analysis pregnant Japanese women
Pregnancy is a critical period during which the diet of pregnant women reflects not only on her own health but also on the health of the fetus. There is evidence to suggest that inadequate nutrition during pregnancy might have unfavourable long-term effects on the developing fetus $^{(1)}$. It may be associated with increased risk of CVD, type 2 diabetes and hypertension in the later life of the child $^{(2)}$. It is therefore important to identify particular groups with poor nutritional status among pregnant women in order to give nutrition education for improving their dietary quality.

Nutritional assessment has traditionally been focused on a detailed examination of energy and nutrient intakes.
Many previous studies examined the nutritional quality (i.e. adequacy or inadequacy) of each nutrient intake during pregnancy by comparison with country-specific nutrient recommendations ${ }^{(3-6)}$. If nutrient intake is inadequate or excessive, however, it is necessary to know which foods are mediating the nutrient supply so that food supply and nutrition education programmes can be directed effectively towards changing the dietary pattern ${ }^{(7)}$. Recently, the dietary pattern approach, namely the measurement of overall diet assessed a posteriori using datadriven techniques such as factor analysis and cluster analysis, has become an important alternative to the traditional single-nutrient approach ${ }^{(8)}$. The use of the dietary pattern 
approach may help to capture some of the complexity of the diet that is often lost in nutrient-based analyses. It is probably able to provide additional information on formulating evidence-based dietary recommendations ${ }^{(9)}$. Cluster analysis, which is as popular as factor analysis, is useful in nutritional studies to identify groups with good or poor nutritional status because it can create groups of people with relatively homogeneous dietary patterns. To our knowledge, however, no study has examined the nutritional adequacy of the dietary patterns identified by cluster analysis among pregnant women.

Here, using the baseline data from the Osaka Maternal and Child Health Study (OMCHS), we evaluated the nutritional adequacy of the dietary patterns identified by cluster analysis in a group of pregnant Japanese women by comparison with the Dietary Reference Intakes (DRI) for Japanese ${ }^{(10)}$.

\section{Subjects and methods}

\section{Subjects and study procedure}

The participants were pregnant women who took part in the baseline survey of the OMCHS, a prospective cohort study investigating preventive and risk factors for maternal and child health problems. Details of the baseline survey of the OMCHS have been published elsewhere ${ }^{(11,12)}$. Briefly, all pregnant women in Neyagawa City, one of the fortythree municipalities in Osaka Prefecture, were recruited between November 2001 and March 2003. Of the 3639 eligible women in Neyagawa City, $627(17 \cdot 2 \%)$ participated in the present survey. In order to increase the sample size, an additional 375 pregnant women living in other municipalities were also enrolled between December 2001 and November 2003. Baseline assessment of the OMCHS was primarily conducted using a set of two self-administered questionnaires. The participants mailed the answered questionnaire to the data management centre. Research technicians completed missing or illogical data by telephone interview. A total of 1002 pregnant women completed the baseline survey.

For the present analysis, the participants aged $<18$ years were excluded $(n 5)$ because indicators of DRI used for assessments of adequacy were different from those for participants aged $\geq 18$ years. Thus, data from 997 pregnant women aged 18-43 years (gestational age: 5-39 weeks) were included in the analysis.

The OMCHS was approved by the Ethics Committee of the Osaka City University School of Medicine. Written informed consent was obtained from each participant.

\section{Dietary assessment}

Dietary habits during the previous month were assessed using a self-administered diet history questionnaire $(\mathrm{DHQ})^{(13-15)}$. This is a 16-page structured questionnaire that consists of the following seven sections: (i) general dietary behaviours; (ii) major cooking methods; (iii) consumption frequency and amount of six alcoholic beverages; (iv) consumption frequency and semi-quantitative portion size of 118 selected food and non-alcoholic beverage items; (v) dietary supplements; (vi) consumption frequency and semi-quantitative portion size of eight staple foods (rice, bread, noodles and other wheat foods) and miso soup (fermented soyabean paste soup), with questions on the size of cups (bowls) usually used for rice and miso soup; and (vii) open-ended items for local foods consumed regularly (one or more times per week) but not appearing in the DHQ. The food and beverage items selected were those commonly consumed in Japan, mainly from a food list used in the National Nutrition Survey of Japan, and standard portion sizes of cups (bowls) for rice and miso soup were derived mainly from several recipe books for Japanese dishes ${ }^{(15)}$.

Estimates of dietary intake for foods (150 items in total), energy and nutrients were calculated using an ad boc computer algorithm for the DHQ, which was based on the Standard Tables of Food Composition in Japan ${ }^{(16)}$. Information on dietary supplements and data from the open-ended questionnaire items were not used in the calculation of dietary intake because of the lack of a reliable composition table for such items in Japan. A more detailed description of the methods used to calculate dietary intake and the validity of the DHQ have been published elsewhere ${ }^{(13-15)}$. Nutrient and food intake values were energyadjusted using the energy-density model, i.e. the percentage of energy intake for macronutrients except for protein, and amount per $4184 \mathrm{~kJ}$ for protein, micronutrients and foods, both to reduce the measurement error common with dietary assessment questionnaires ${ }^{(17,18)}$ and to avoid biased grouping due to variation in body size and energy requirement ${ }^{(17)}$.

\section{Determination of nutritional adequacy}

To assess the adequacy of nutrient intake, we compared the nutrient intake estimated by the DHQ to the corresponding dietary reference value according to the DRI ${ }^{(10)}$. We show a brief comparison of the DRI for the USA and Canada $^{(19)}$ and Japan ${ }^{(10)}$, for reference, in Appendix 1. Of the total thirty-four nutrients presented in the DRI, five nutrients (biotin, chromium, molybdenum, selenium and iodine) were excluded from the present study because of lack of food composition tables for such items in Japan. In the DRI for pregnant women, nutrient recommendations are set for some nutrients as increments of the nonpregnant period because of the many unique changes in physiology and nutrition needs that occur during pregnancy and lactation ${ }^{(10)}$. The detailed reference values for pregnant women are shown in Appendix 2.

As the DRI for most nutrients are expressed as amounts per day ${ }^{(10)}$, each reference value was energyadjusted using the density model (i.e. percentage of energy intake for macronutrients except for protein and amount per $4184 \mathrm{~kJ}$ for protein and micronutrients) in 
accordance with the units of nutrient intake estimated by the DHQ. The energy-adjusted reference values for protein and micronutrients were calculated as follows: energy-adjusted reference value (amount per $4184 \mathrm{~kJ}$ ) = reference value (amount/d)/estimated energy requirement $($ EER, $\mathrm{kJ} / \mathrm{d}) \times 4184(\mathrm{~kJ})$.

For nutrients with an Estimated Average Requirement (EAR), namely protein, vitamin A expressed as retinol equivalent (RE), vitamins $B_{1}$ and $B_{2}$, niacin expressed as niacin equivalent (computed as niacin $(\mathrm{mg})+$ protein (mg)/6000), vitamins $\mathrm{B}_{6}$ and $\mathrm{B}_{12}$, folate, vitamin $\mathrm{C}$, calcium, magnesium, iron, zinc and copper ${ }^{(10)}$, observed energyadjusted intake levels below the energy-adjusted EAR, used as a cut-off value, were considered as inadequate. For iron, the EAR cut-point method cannot be used because of the seriously skewed distribution of the requirement for menstruating women ${ }^{(19,20)}$. However, as pregnant women are not menstruating, the distribution of their iron requirements approaches symmetry according to previous reports ${ }^{(20,21)}$. In accordance with previous studies ${ }^{(21,22)}$, we also used the EAR cut-point method for iron.

In the Japanese DRI ${ }^{(10)}$, the Tentative Dietary Goal for Preventing Lifestyle-related Disease (DG) is defined as the average daily nutrient intake level (or ranges) that Japanese should currently aim to consume primarily to prevent chronic diseases (e.g. CVD (hypertension, hyperlipidaemia, stroke and myocardial infarction) and cancer (especially, stomach cancer)), which basically corresponds to the Acceptable Macronutrient Distribution Ranges (AMDR) of the US and Canadian DRI ${ }^{(19)}$ (Appendix 1). The DG is given for total fat, SFA, cholesterol, carbohydrate, dietary fibre and sodium expressed as salt equivalent $($ salt $(\mathrm{g} / \mathrm{d})=\operatorname{sodium}(\mathrm{g} / \mathrm{d}) \times 58.5 / 23)$ (Appendix 2). For these nutrients, energy-adjusted intake levels outside the range of the corresponding DG were considered inadequate ${ }^{(10)}$.

For nutrients with Adequate Intake (AI) such as n-6 PUFA, $n$-3 PUFA, vitamin $\mathrm{D}$, vitamin $\mathrm{E}$ expressed as $\alpha$-tocopherol, vitamin $\mathrm{K}$, pantothenic acid, potassium, phosphate and manganese, inadequacy of intake cannot be determined even if their intake levels are less than the $\mathrm{AI}^{(10,19)}$. Therefore, for these nutrients only, the energyadjusted intake levels at or above $\mathrm{AI}$ were exceptionally considered as adequate ${ }^{(10)}$.

\section{Assessment of lifestyle variables}

Lifestyle variables such as age, gestation, parity, cigarette smoking, dietary change in the past 1 month, current occupation, education and household income were obtained from another questionnaire designed for the present survey. Age was classified into two categories ( $<30$ and $\geq 30$ years); gestation into three categories $\left(<16,16-27\right.$ and $\geq 28$ weeks) following the $\mathrm{DRI}^{(10)}$. Parity $(0$ and $\geq 1$ ), cigarette smoking (never, former and current), dietary change in the previous 1 month compared with non-pregnancy (none or seldom, slight and substantial), occupation (housewife and outside work), participant's and partner's education $(<13,13-14$ and $\geq 15$ years) and household income ( $<4000000,4000000$ 5999999 and $\geq 6000000$ Japanese yen/year) were assessed.

Physical activity level was obtained from the DHQ, which queried participants about their occupation and leisure-time activity. One answer was chosen from four categories (low, relatively low, moderate and heavy physical activity level), which reference to the Recommended Dietary Allowance for Japanese ${ }^{(23)}$. This classification was revised from four to three categorizations by combining the heavy and moderate levels according to the $\mathrm{DRI}^{(24)}$. In accordance with the revision, the categories were considered to be level I (low), level II (moderate) or level III (high), and were then used to obtain the EER for the individual ${ }^{(10,24)}$. Current supplement use was also obtained from the DHQ.

\section{Statistical analysis}

Before analysis, food items were grouped together to reduce complexity. The grouping scheme was generally based on the principles of similarity of nutrient profiles and culinary usage of the foods, mainly according to the food composition tables of Japanese foods ${ }^{(16)}$, and classification of food groups used in the National Nutrition Survey in Japan ${ }^{(25)}$. Of the total 150 food items included in the DHQ, three items (nutritional supplement bars, soup of the noodle and drinking water) were difficult to group or rarely eaten. They were therefore omitted from the study. Finally, 147 food items included in the DHQ were classified into thirty-three food groups (Table 1). To remove the extraneous effect of variables with large variances, we standardized intake of energy-adjusted food group to a mean of zero and standard deviation of one.

Cluster analysis was performed using the FASTCLUS procedure in the SAS statistical software package version $9 \cdot 1$ (SAS Institute Inc., Cary, NC, USA) ${ }^{(26)}$. This procedure applies the $K$-means method to classify participants into a predetermined number of mutually exclusive groups by comparing Euclidean distances between each participant and each cluster centre in an interactive process until no further changes occur. To identify the optimal number of clusters, several runs were conducted varying the number of clusters from two to six. The final cluster solution was selected by comparing the ratio of betweencluster variance to within-cluster variance divided by the number of clusters. Based on these determinations and on the nutritional meaningfulness of clusters, we selected the three-cluster solution as the most appropriate number.

The median differences in the intake of energy-adjusted food groups and nutrients across clusters were examined by the Kruskal-Wallis test. To examine the nutritional inadequacy of nutrient intake of each dietary pattern, we estimated the percentage of participants whose intake was below the EAR or outside the DG. The nutrients with a set 
Table 1 The thirty-three food groups used in the present study for dietary pattern analysis

\begin{tabular}{|c|c|}
\hline Food groups & Food items* \\
\hline Rice & $\begin{array}{l}\text { Well-milled rice, rice with barley ( } 70 \% \text { rice and } 30 \% \text { barley), rice with germ, half-milled rice, } 70 \% \text { milled } \\
\text { rice, brown rice }\end{array}$ \\
\hline Bread & White bread, butter-roll, croissant, pizza, cornflakes, Japanese-style pancakes \\
\hline Noodles & Japanese noodle (buckwheat/Japanese wheat noodle), instant noodles, Chinese noodles, pasta, spaghetti \\
\hline Potatoes & White potatoes, French fries, sweet potatoes, taro, konnyaku \\
\hline Nuts & Peanuts, other types of nuts \\
\hline Pulses & $\begin{array}{l}\text { Tofu (soyabean curd), tofu products such as atsuage (deep-fried tofu cutlet), ganmodoki (deep-fried tofu } \\
\text { burger), aburaage (deep-fried tofu pouch), natto (fermented soyabeans), cooked beans, miso as seasoning }\end{array}$ \\
\hline Sugar & Sugar for coffee and tea, sugar for cooking, jam, marmalade \\
\hline Confectioneries & $\begin{array}{l}\text { Japanese sweetened bun, hot-cake, potato chips, senbei and arare (rice snacks), crackers, salted } \\
\text { snacks, Japanese sweets with or without azuki-beans, cakes, hard cookies, soft cookies, chocolates, } \\
\text { candies, caramels, chewing gums, jellies, doughnut, ice cream }\end{array}$ \\
\hline Butter & Butter \\
\hline Vegetable oil & Margarine, vegetable oils, salad dressings with oil, mayonnaise \\
\hline Fruits & $\begin{array}{l}\text { Oranges, grapefruits, bananas, apples, strawberries, grapes, peaches, pears, kiwifruits, persimmons, } \\
\text { melons, water melon, raisons, canned fruits }\end{array}$ \\
\hline Green and yellow vegetables & Carrots, pumpkins, tomatoes, green pepper, broccoli, lettuce, green leafy vegetables such as spinach \\
\hline White vegetables & $\begin{array}{l}\text { Cabbage, cucumber, Chinese cabbage, bean sprouts, Japanese radish, onion, cauliflower, aubergine, } \\
\text { burdock, lotus root }\end{array}$ \\
\hline Pickled vegetables & Salted pickles, umeboshi (pickled and dried plum), kimchi (Korean pickles) \\
\hline Mushrooms & Shiitake mushroom, shimeji mushroom, enoki mushroom \\
\hline Seaweeds & Wakame seaweed, purple laver, brown algae \\
\hline Alcoholic beverages & Beer, sake (rice wine), shochu (distilled spirits), chuhai (shochu highball), whisky, wine \\
\hline Fruit and vegetable juice & Vegetable juice, tomato juice, $100 \%$ fruit juice, sweetened fruit drinks ( $50 \%$ fruit) \\
\hline Soft drinks & Cola, non-fruit juices, soft drinks without sugar such as sports beverages, lactic acid bacteria beverages \\
\hline Japanese and Chinese tea & Green tea, oolong tea, barley tea \\
\hline Tea & Black tea \\
\hline Coffee and cocoa & Coffee, cocoa \\
\hline Dairy products & Whole milk, low-fat milk, skim milk, yoghurt, cheese, cottage cheese, coffee cream \\
\hline Fish & $\begin{array}{l}\text { Eel, fish with white meat (sea bream, flatfish, cod and others), fish with a blue back (mackerel, sardine, } \\
\text { herring and others), fish with red meat (tuna, salmon, skipjack) }\end{array}$ \\
\hline Shellfish & Shrimp, squid, octopus, oysters, other shellfish \\
\hline Sea products & $\begin{array}{l}\text { Dried fish, small fish with bones, canned tuna, fish eggs, boiled fish in soya sauce, salted guts, surimi } \\
\text { (ground fish meat) products }\end{array}$ \\
\hline Chicken & Chicken, liver \\
\hline Beef and pork & Beef, pork, ground beef/pork \\
\hline Processed meat & Ham, sausage, bacon, salami \\
\hline Eggs & Eggs \\
\hline Miso soup & Miso (fermented soyabean paste) soup \\
\hline Other soup & Corn soup, Chinese soup \\
\hline Salt-containing seasonings & $\begin{array}{l}\text { Table salt, salt and salt-rich seasonings used during cooking, soya sauce, non-oil dressings, curry or } \\
\text { stew roux }\end{array}$ \\
\hline
\end{tabular}

${ }^{\star}$ Foods listed were from a self-administered diet history questionnaire.

AI were excluded from the calculation of the prevalence of inadequacy because no firm conclusion could be drawn on inadequacy if usual intake was less than $\mathrm{AI}^{(10,19)}$. The $\chi^{2}$ test was used to examine differences between variables expressed as a proportion, such as lifestyle variables and the prevalence of inadequacy.

To assess the overall nutritional inadequacy of each participant, we counted the number of nutrients that did not meet the DRI among fourteen and six nutrients with an EAR and a DG, respectively, in accordance with previous studies $^{(27,28)}$. The nutrients with an AI were excluded from this analysis because of the reason mentioned above. Therefore, this number ranged from 0 (meeting all twenty DRI recommendations) to 20 (meeting none of the twenty DRI recommendations).

All statistical analyses were performed using SAS statistical software version 9.1 (SAS Institute Inc.). A twosided $P$ value of 0.05 was considered significant.

\section{Results}

Three clusters of dietary pattern were identified (Table 2). We descriptively labelled them (i) 'meat and eggs' ( $n$ 423; $42 \cdot 4 \%$ ); (ii) 'wheat products' ( $n 371 ; 37 \cdot 2 \%$ ); and (iii) 'rice, fish and vegetables' ( $n$ 203; 20.4\%) patterns, based on the food groups predominant in each cluster. The 'meat and eggs' pattern was characterized by significantly higher median intakes of beef and pork, processed meat, eggs, coffee and cocoa and dairy products. The 'wheat products' pattern was characterized by significantly higher median intakes of bread, noodles, confectioneries, fruit and vegetable juice and soft drinks. The 'rice, fish and vegetables' pattern was characterized by significantly higher median intakes of rice, potatoes, pulses, fruit, green and yellow vegetables, white vegetables, pickled vegetables, mushrooms, seaweeds, Japanese and Chinese tea, fish, shellfish, sea products, chicken, miso soup and salt-containing seasonings. 
Table 2 Daily energy-adjusted intakes of thirty-three food groups ( $\mathrm{g} / 4184 \mathrm{~kJ})$ assessed with a self-administered diet history questionnaire across the three dietary patterns identified among 997 pregnant Japanese women aged 18-43 years

\begin{tabular}{|c|c|c|c|c|c|c|c|c|c|}
\hline \multirow[b]{3}{*}{ Food group } & & & \multicolumn{6}{|c|}{ Dietary pattern* } & \multirow[b]{3}{*}{$P$ valuet } \\
\hline & \multicolumn{2}{|c|}{$\begin{array}{c}\text { All } \\
(n \text { 997) }\end{array}$} & \multicolumn{2}{|c|}{$\begin{array}{l}\text { Meat and eggs } \\
\qquad(n \text { 423) }\end{array}$} & \multicolumn{2}{|c|}{$\begin{array}{l}\text { Wheat products } \\
\qquad(\text { n 371) }\end{array}$} & \multicolumn{2}{|c|}{$\begin{array}{l}\text { Rice, fish and vegetables } \\
(n \text { 203) }\end{array}$} & \\
\hline & Median & IQR & Median & IQR & Median & IQR & Median & IQR & \\
\hline Rice & $130 \cdot 0$ & 98,165 & $124 \cdot 0$ & 95,150 & $135 \cdot 0$ & 93,171 & $146 \cdot 0$ & 109,185 & $<0.001$ \\
\hline Bread & $34 \cdot 3$ & $22 \cdot 5,46 \cdot 7$ & $34 \cdot 4$ & $25 \cdot 2,44 \cdot 9$ & $39 \cdot 5$ & $27 \cdot 8,55 \cdot 5$ & $23 \cdot 7$ & $12 \cdot 3,33 \cdot 9$ & $<0.001$ \\
\hline Noodles & $36 \cdot 0$ & $18 \cdot 4,57 \cdot 4$ & $34 \cdot 8$ & $18 \cdot 8,52 \cdot 4$ & $\overline{39 \cdot 9}$ & $18 \cdot 4,66 \cdot 2$ & $32 \cdot 8$ & $17 \cdot 3,55 \cdot 1$ & 0.020 \\
\hline Potatoes & $11 \cdot 8$ & $8 \cdot 0,17 \cdot 8$ & $12 \cdot 1$ & $8 \cdot 7,17 \cdot 2$ & $\frac{9 \cdot 4}{9 \cdot 4}$ & $6 \cdot 6,13 \cdot 0$ & $19 \cdot 5$ & $11 \cdot 8,28 \cdot 6$ & $<0.001$ \\
\hline Nuts & 0.0 & $0.0,0.4$ & 0.0 & $0.0,0.4$ & $0 \cdot 0$ & $0 \cdot 0,0.4$ & $\overline{0.0}$ & $0.0,0.7$ & 0.006 \\
\hline Pulses & $19 \cdot 4$ & $11 \cdot 1,29 \cdot 3$ & $22 \cdot 3$ & $14 \cdot 5,31 \cdot 5$ & $11 \cdot 4$ & $6 \cdot 6,18 \cdot 4$ & $28 \cdot 9$ & $20 \cdot 6,44 \cdot 4$ & $<0.001$ \\
\hline Sugar & $6 \cdot 0$ & $4 \cdot 5,8 \cdot 2$ & $6 \cdot 3$ & $4 \cdot 8,9 \cdot 1$ & $5 \cdot 3$ & $3 \cdot 8,7 \cdot 5$ & $\frac{6 \cdot 7}{6 \cdot}$ & $5 \cdot 1,7 \cdot 9$ & $<0.001$ \\
\hline Confectioneries & $37 \cdot 6$ & $25 \cdot 5,52 \cdot 1$ & $33 \cdot 8$ & $23 \cdot 5,45 \cdot 8$ & $50 \cdot 3$ & $35 \cdot 9,71 \cdot 1$ & $2 \overline{7 \cdot 5}$ & $18 \cdot 7,39 \cdot 1$ & $<0.001$ \\
\hline Butter & $0 \cdot 1$ & $0.0,0.6$ & 0.2 & $0 \cdot 0,0 \cdot 7$ & $0 \cdot 0$ & $0.0,0.5$ & $0 \cdot 2$ & $0 \cdot 0,0 \cdot 6$ & 0.016 \\
\hline Vegetable oil & $12 \cdot 0$ & $9 \cdot 0,15 \cdot 5$ & $1 \overline{3 \cdot 4}$ & $10 \cdot 5,16 \cdot 8$ & $10 \cdot 8$ & $7 \cdot 8,13 \cdot 8$ & $11 \cdot 4$ & $8 \cdot 4,15 \cdot 2$ & $<0.001$ \\
\hline Fruits & $48 \cdot 2$ & $26 \cdot 8,80 \cdot 7$ & $\overline{44 \cdot 8}$ & $27 \cdot 5,70 \cdot 8$ & $45 \cdot 1$ & $22 \cdot 7,79 \cdot 9$ & $65 \cdot 7$ & $35 \cdot 4,92 \cdot 0$ & $<0.001$ \\
\hline Green and yellow vegetables & $32 \cdot \overline{3}$ & $20 \cdot 9,48 \cdot 7$ & $36 \cdot 3$ & $25 \cdot 9,51 \cdot 0$ & $22 \cdot 2$ & $14 \cdot 7,31 \cdot 8$ & $\overline{51 \cdot 7}$ & $34 \cdot 9,77 \cdot 5$ & $<0.001$ \\
\hline White vegetables & $40 \cdot 2$ & $27 \cdot 9,55 \cdot 8$ & $44 \cdot 0$ & $35 \cdot 0,57 \cdot 2$ & $28 \cdot 1$ & $19 \cdot 9,39 \cdot 2$ & $\overline{60 \cdot 6}$ & $42 \cdot 0,80 \cdot 2$ & $<0.001$ \\
\hline Pickled vegetables & $2 \cdot 5$ & $1 \cdot 1,6 \cdot 0$ & $2 \cdot 8$ & $1 \cdot 0,6 \cdot 2$ & $2 \cdot 2$ & $0.9,5.0$ & $\overline{3 \cdot 3}$ & $1 \cdot 2,7 \cdot 9$ & 0.003 \\
\hline Mushrooms & $3 \cdot 6$ & $2 \cdot 0,7 \cdot 9$ & $4 \cdot 4$ & $2 \cdot 4,7 \cdot 8$ & $2 \cdot 3$ & $1 \cdot 4,3 \cdot 8$ & $\overline{9 \cdot 0}$ & $4 \cdot 5,14 \cdot 7$ & $<0.001$ \\
\hline Seaweeds & $3 \cdot 9$ & $2 \cdot 3,9 \cdot 3$ & $4 \cdot 3$ & $2 \cdot 7,8 \cdot 8$ & $2 \cdot 6$ & $1 \cdot 4,4 \cdot 4$ & $1 \overline{2 \cdot 0}$ & $6 \cdot 2,17 \cdot 9$ & $<0.001$ \\
\hline Alcoholic beverages & $0 \cdot 0$ & $0.0,0.0$ & 0.0 & $0.0,0.0$ & $0 \cdot 0$ & $0.0,0.0$ & 0.0 & $0 \cdot 0,0 \cdot 0$ & $0 \cdot 140$ \\
\hline Fruit and vegetable juice & $26 \cdot 2$ & $0 \cdot 0,62 \cdot 6$ & $18 \cdot 8$ & $0 \cdot 0,52 \cdot 0$ & $33 \cdot 8$ & $5 \cdot 3,78 \cdot 5$ & $22 \cdot 0$ & $0 \cdot 0,54 \cdot 4$ & $<0.001$ \\
\hline Japanese and Chinese tea & $310 \cdot 0$ & 196,475 & $304 \cdot 0$ & 199,431 & $2 \overline{95 \cdot 0}$ & 186,470 & $365 \cdot 0$ & 224,545 & 0.002 \\
\hline Tea & $11 \cdot 1$ & $0 \cdot 0,36$ & $11 \cdot 1$ & $0 \cdot 0,38 \cdot 4$ & $12 \cdot 6$ & $0 \cdot 0,37 \cdot 5$ & $9 \cdot 3$ & $0 \cdot 0,32 \cdot 8$ & 0.256 \\
\hline Coffee and cocoa & $29 \cdot 1$ & $0.0,83$ & $47 \cdot 8$ & $5 \cdot 7,94 \cdot 8$ & $\overline{19 \cdot 2}$ & $0 \cdot 0,73 \cdot 4$ & $19 \cdot 2$ & $0 \cdot 0,64 \cdot 1$ & $<0.001$ \\
\hline Soft drinks & $14 \cdot 0$ & $0 \cdot 0,42 \cdot 3$ & $\overline{10 \cdot 4}$ & $0 \cdot 0,30 \cdot 6$ & $24 \cdot 2$ & $2 \cdot 1,74 \cdot 4$ & $6 \cdot 0$ & $0 \cdot 0,28 \cdot 2$ & $<0.001$ \\
\hline Dairy products & $89 \cdot 2$ & $46 \cdot 0,127$ & $103 \cdot 0$ & $69 \cdot 2,145$ & $\overline{68.9}$ & $31 \cdot 0,111$ & $77 \cdot 4$ & $35 \cdot 0,116$ & $<0.001$ \\
\hline Fish & $11 \cdot \overline{7}$ & $7 \cdot 3,16 \cdot 0$ & 11.9 & $8 \cdot 1,15 \cdot 7$ & 8.9 & $5 \cdot 0,12 \cdot 5$ & $17 \cdot 9$ & $13 \cdot 3,24 \cdot 5$ & $<0.001$ \\
\hline Shellfish & $4 \cdot 8$ & $2 \cdot 4,7 \cdot 6$ & $4 \cdot 9$ & $2 \cdot 7,7 \cdot 6$ & $3 \cdot 9$ & $1 \cdot 6,6 \cdot 6$ & $6 \cdot 1$ & $3 \cdot 1,10 \cdot 2$ & $<0.001$ \\
\hline Sea products & $6 \cdot 5$ & $3 \cdot 7,10 \cdot 4$ & $7 \cdot 2$ & $4 \cdot 0,10 \cdot 5$ & $4 \cdot 6$ & $2 \cdot 4,7 \cdot 6$ & $1 \overline{0 \cdot 3}$ & $6 \cdot 1,15 \cdot 2$ & $<0.001$ \\
\hline Chicken & $6 \cdot 7$ & $4 \cdot 5,12 \cdot 4$ & $8 \cdot 0$ & $5 \cdot 4,14 \cdot 4$ & $5 \cdot 2$ & $3 \cdot 6,8 \cdot 1$ & $8 \cdot 1$ & $5 \cdot 1,14 \cdot 5$ & $<0.001$ \\
\hline Beef and pork & $17 \cdot 5$ & $12 \cdot 1,25 \cdot 1$ & $21 \cdot 2$ & $15 \cdot 0,29 \cdot 0$ & $14 \cdot 4$ & $9 \cdot 8,20 \cdot 4$ & $1 \overline{7 \cdot 3}$ & $12 \cdot 0,23 \cdot 2$ & $<0.001$ \\
\hline Processed meat & $2 \cdot 9$ & $1 \cdot 7,5 \cdot 1$ & 3.5 & $2 \cdot 2,6 \cdot 6$ & $2 \cdot 6$ & $1 \cdot 5,4 \cdot 2$ & $2 \cdot 2$ & $1 \cdot 4,4 \cdot 2$ & $<0.001$ \\
\hline Eggs & $15 \cdot 2$ & $8 \cdot 0,26 \cdot 5$ & $2 \overline{0 \cdot 9}$ & $12 \cdot 1,29 \cdot 8$ & $11 \cdot 8$ & $5 \cdot 0,21 \cdot 1$ & $14 \cdot 8$ & $7 \cdot 3,25 \cdot 9$ & $<0.001$ \\
\hline Miso soup & $37 \cdot 3$ & $14 \cdot 2,64 \cdot 3$ & $\overline{35 \cdot 8}$ & $13 \cdot 8,57 \cdot 7$ & $27 \cdot 3$ & $6 \cdot 8,52 \cdot 5$ & $63 \cdot 1$ & $36 \cdot 3,94 \cdot 1$ & $<0.001$ \\
\hline Other soup & $0 \cdot 0$ & $0 \cdot 0,4 \cdot 2$ & 0.0 & $0 \cdot 0,4 \cdot 1$ & 0.0 & $0 \cdot 0,3 \cdot 4$ & 0.0 & $0 \cdot 0,5 \cdot 0$ & 0.005 \\
\hline Salt-containing seasonings & $6 \cdot 1$ & $4 \cdot 5,7 \cdot 9$ & $6 \cdot 7$ & $5 \cdot 2,8 \cdot 4$ & $4 \cdot 7$ & $3 \cdot 6,6 \cdot 0$ & $7 \cdot 2$ & $5 \cdot 7,8 \cdot 9$ & $<0.001$ \\
\hline
\end{tabular}

IQR, interquartile range.

${ }^{*}$ Cluster names were basically based on the food groups with high intakes.

tKruskal-Wallis test was used to test the median differences across clusters. The highest median values are underlined.

Table 3 shows participant characteristics for non-dietary variables across the three dietary patterns. Participants with the 'rice, fish and vegetables' pattern were more likely to be current non-smokers, supplement users and had an older gestational age, higher own education and a partner with higher education than those with other dietary patterns. In contrast, participants with the 'wheat products' pattern were more likely to be current smokers, few supplement users and had younger gestational age, lower own education and a partner with lower education. Participants with the 'meat and eggs' pattern had intermediate characteristics between those with the 'rice, fish and vegetables' and 'wheat products' patterns. Age, parity, dietary change, physical activity level, occupation and household income did not differ across the three dietary patterns.

Table 4 shows the median energy-adjusted nutrient intakes and the prevalences of participants who did not meet the DRI recommendations across the three dietary patterns (Table 4). The 'meat and eggs' pattern had significantly higher median intakes of energy, total fat, SFA, cholesterol and $n$-3 PUFA, but significantly the lowest median intake of carbohydrates. However, the 'meat and eggs' pattern showed significantly higher prevalence of inadequacy in these nutrients except for $n-3$ PUFA among the three dietary patterns. The 'wheat products' pattern had significantly higher median intake of carbohydrates, but had significantly lower median intakes of energy and all the nutrients examined. The 'wheat products' pattern showed the highest prevalence of inadequacy in dietary fibre and all nutrients with an EAR. In contrast, the 'rice, fish and vegetables' pattern had significantly higher intakes of dietary fibre, sodium and all nutrients with an EAR and AI except for $n-3$ PUFA. The 'rice, fish and vegetables' pattern showed significantly lower prevalence of inadequacy in total fat, SFA, dietary fibre and nutrients with an EAR except for vitamin $\mathrm{B}_{2}$ and calcium, but the highest prevalence of inadequacy in sodium. For nutrients with an AI, the median intakes of eight nutrients except vitamin D in the 'meat and eggs' pattern, five nutrients ( $n-6$ and $n-3$ PUFA, vitamin E, vitamin $\mathrm{K}$ and manganese) in the 'wheat products' pattern and all 
Table 3 Subject characteristics for non-dietary variables across the three dietary patterns identified among 997 pregnant Japanese women aged $18-43$ years

\begin{tabular}{|c|c|c|c|c|c|}
\hline \multirow[b]{2}{*}{ Characteristics } & \multirow[b]{2}{*}{$\begin{array}{c}\text { All } \\
(n 997)\end{array}$} & \multicolumn{3}{|c|}{ Dietary pattern* } & \multirow[b]{2}{*}{$P$ value } \\
\hline & & $\begin{array}{l}\text { Meat and eggs } \\
\qquad(n 423)\end{array}$ & $\begin{array}{l}\text { Wheat products } \\
\quad(n \text { 371) }\end{array}$ & $\begin{array}{l}\text { Rice, fish and vegetables } \\
\qquad(n \text { 203) }\end{array}$ & \\
\hline \multicolumn{6}{|l|}{ Age (years) $\ddagger$} \\
\hline$<30$ & $46 \cdot 9$ & $45 \cdot 4$ & $50 \cdot 9$ & $42 \cdot 9$ & $0 \cdot 125$ \\
\hline$\geq 30$ & $53 \cdot 1$ & $54 \cdot 6$ & $49 \cdot 1$ & $57 \cdot 1$ & \\
\hline \multicolumn{6}{|l|}{ Gestation (weeks) $\ddagger$} \\
\hline$<16$ & $38 \cdot 8$ & $34 \cdot 8$ & $46 \cdot 4$ & $33 \cdot 5$ & 0.005 \\
\hline $16-27$ & $53 \cdot 7$ & $57 \cdot 7$ & $46 \cdot 4$ & $58 \cdot 6$ & \\
\hline$\geq 28$ & $7 \cdot 5$ & $7 \cdot 6$ & $7 \cdot 3$ & $7 \cdot 9$ & \\
\hline Parity of one or more (\%) & $51 \cdot 3$ & $54 \cdot 6$ & $47 \cdot 2$ & $51 \cdot 7$ & $0 \cdot 111$ \\
\hline \multicolumn{6}{|l|}{ Cigarette smoking (\%) } \\
\hline Never & $69 \cdot 8$ & $74 \cdot 0$ & $62 \cdot 0$ & $75 \cdot 4$ & $<0.001$ \\
\hline Former & $12 \cdot 0$ & $10 \cdot 4$ & $12 \cdot 9$ & $13 \cdot 8$ & \\
\hline Current & $18 \cdot 2$ & $15 \cdot 6$ & $25 \cdot 1$ & $10 \cdot 8$ & \\
\hline \multicolumn{6}{|c|}{$\begin{array}{l}\text { Dietary change in the previous } 1 \text { month compared } \\
\text { with non-pregnancy (\%) }\end{array}$} \\
\hline None or seldom & $29 \cdot 9$ & $32 \cdot 4$ & $29 \cdot 4$ & $25 \cdot 6$ & 0.236 \\
\hline Slight & $43 \cdot 5$ & $43 \cdot 7$ & $41 \cdot 2$ & $47 \cdot 3$ & \\
\hline Substantial & $26 \cdot 6$ & $23 \cdot 9$ & $29 \cdot 4$ & $27 \cdot 1$ & \\
\hline Supplement user (\%) & $20 \cdot 2$ & $19 \cdot 6$ & $16 \cdot 3$ & $28 \cdot 6$ & 0.006 \\
\hline \multicolumn{6}{|l|}{ Physical activity level (\%) } \\
\hline Level I (low) & $60 \cdot 1$ & $58 \cdot 4$ & $64 \cdot 7$ & $55 \cdot 2$ & $0 \cdot 134$ \\
\hline Level II (moderate) & $39 \cdot 1$ & $40 \cdot 4$ & $34 \cdot 8$ & $44 \cdot 3$ & \\
\hline Level III (high) & 0.8 & $1 \cdot 2$ & 0.5 & 0.5 & \\
\hline \multicolumn{6}{|l|}{ Occupation (\%) } \\
\hline Housewife & $71 \cdot 1$ & $73 \cdot 1$ & $67 \cdot 9$ & $72 \cdot 9$ & 0.232 \\
\hline Outside work & $28 \cdot 9$ & $27 \cdot 0$ & $32 \cdot 1$ & $27 \cdot 1$ & \\
\hline \multicolumn{6}{|l|}{ Education (years; \%) } \\
\hline$<13$ & 31.9 & $32 \cdot 2$ & $36 \cdot 4$ & $23 \cdot 2$ & 0.001 \\
\hline $13-14$ & $41 \cdot 4$ & $40 \cdot 4$ & $42 \cdot 6$ & $41 \cdot 4$ & \\
\hline$\geq 15$ & $26 \cdot 7$ & $27 \cdot 4$ & $21 \cdot 0$ & $35 \cdot 5$ & \\
\hline \multicolumn{6}{|c|}{ Partner's education (years; \%) } \\
\hline$<13$ & $39 \cdot 7$ & $37 \cdot 8$ & $43 \cdot 1$ & $37 \cdot 4$ & 0.007 \\
\hline $13-14$ & $17 \cdot 2$ & $16 \cdot 1$ & $20 \cdot 8$ & $12 \cdot 8$ & \\
\hline$\geq 15$ & $43 \cdot 1$ & $46 \cdot 1$ & $36 \cdot 1$ & $49 \cdot 8$ & \\
\hline \multicolumn{6}{|c|}{ Household income (Japanese yen§/year; \%) } \\
\hline$<4000000$ & $29 \cdot 8$ & $30 \cdot 5$ & $30 \cdot 2$ & $27 \cdot 6$ & 0.358 \\
\hline $4000000-5999999$ & $40 \cdot 3$ & $37 \cdot 8$ & $43 \cdot 4$ & 39.9 & \\
\hline$\geq 6000000$ & $29 \cdot 9$ & $31 \cdot 7$ & $26 \cdot 4$ & $32 \cdot 5$ & \\
\hline
\end{tabular}

${ }^{*}$ Cluster names were basically based on the food groups with high intakes.

$+\chi^{2}$ test was used to test differences between categorical variables.

$\ddagger$ Categorizations were according to the Dietary Reference Intakes for Japanese, $2010^{(10)}$

$\S$ Japanese yen $=0.0074$ Euros $=0.0067$ UK pound $=0.0110$ US dollars in November 2009.

nine nutrients in the 'rice, fish and vegetables' patterns exceeded the recommended levels.

To examine the overall nutritional inadequacy of each dietary pattern, we counted the number of nutrients that did not meet the EAR or DG. A significant difference in overall inadequacy was observed among the three dietary patterns: the median numbers (interquartile ranges) of nutrients not meeting EAR or DG were $10 \cdot 0(8 \cdot 0,11 \cdot 0)$ in the 'meat and eggs' pattern, $11 \cdot 0(10 \cdot 0,12 \cdot 0)$ in the 'wheat products' pattern and $8 \cdot 0(6 \cdot 0,9 \cdot 0)$ in the 'rice, fish and vegetables' pattern $(P<0 \cdot 001)$.

\section{Discussion}

Nearly all the studies on the identification of dietary patterns of pregnant women have been conducted primarily by using factor analysis ${ }^{(29-33)}$. To the best our knowledge, the present study is the first one to identify the dietary patterns of pregnant women using cluster analysis. We identified three dietary patterns, labelled as the 'meat and eggs', 'wheat products' and 'rice, fish and vegetables' patterns, from a validated dietary assessment questionnaire among 997 pregnant Japanese women aged 18-43 years. We evaluated the nutritional adequacy of each derived dietary pattern by comparison with the DRI. Our main finding was that participants with the 'rice, fish and vegetables' pattern had a better nutritional profile with lower prevalence of inadequacy for many essential micronutrients than participants with the other two dietary patterns.

Cluster analysis explores the categorization of participants into groups on the basis of similarity in food intake. It is a useful method for focusing attention on groups with good or poor nutritional status. The participants with the 
Table 4 Daily energy-adjusted nutrient intakes (unit/4184 kJ) assessed with a self-administered DHQ and prevalence of participants with inadequate nutrient intakes compared with the DRI for Japanese, 2010, using the cut-point method across three dietary patterns identified among 997 pregnant Japanese women aged 18-43 years

\begin{tabular}{|c|c|c|c|c|c|c|c|c|c|c|c|c|c|}
\hline \multirow[b]{3}{*}{ Nutrient* } & \multirow{2}{*}{\multicolumn{3}{|c|}{$\begin{array}{c}\text { All } \\
(n 997)\end{array}$}} & \multicolumn{9}{|c|}{ Dietary pattern } & \multirow[b]{3}{*}{$P$ value } \\
\hline & & & & \multicolumn{3}{|c|}{$\begin{array}{l}\text { Meat and eggs } \\
\quad(n 423)\end{array}$} & \multicolumn{3}{|c|}{$\begin{array}{l}\text { Wheat products } \\
\text { ( } n \text { 371) }\end{array}$} & \multicolumn{3}{|c|}{$\begin{array}{l}\text { Rice, fish and vegetables } \\
\qquad(n \text { 203) }\end{array}$} & \\
\hline & Median & IQR & $\begin{array}{c}\text { Prevalence of } \\
\text { inadequacy }(\%)+\end{array}$ & Median & IQR & $(\%) \dagger$ & Median & IQR & $(\%) \dagger$ & Median & IQR & $(\%) \dagger$ & \\
\hline $\begin{array}{l}\text { Energy intake }(\mathrm{kJ} / \mathrm{d}) \\
\text { Nutrient with } D G\end{array}$ & $7473 \cdot 0$ & 6467,8628 & - & $\underline{7579 \cdot 0}$ & 6659,8694 & - & $7151 \cdot 0$ & 6055,8610 & - & $7528 \cdot 0$ & 6528,8548 & - & - \\
\hline Total fat (\% energy) & $29 \cdot 9$ & $26 \cdot 3,33 \cdot 4$ & $71 \cdot 3$ & $32 \cdot 1$ & $29 \cdot 4,35 \cdot 1$ & $84 \cdot 4$ & $27 \cdot 4$ & $24 \cdot 4,30 \cdot 6$ & $61 \cdot 7$ & $28 \cdot 8$ & $26 \cdot 0,32 \cdot 3$ & $61 \cdot 6$ & $<0.001$ \\
\hline SFA (\% energy) & $8 \cdot 3$ & $7 \cdot 1,9 \cdot 7$ & $78 \cdot 5$ & $9 \cdot 0$ & $8 \cdot 0,10 \cdot 2$ & $91 \cdot 0$ & $7 \cdot 9$ & $6 \cdot 5,9 \cdot 4$ & $70 \cdot 1$ & $7 \cdot 6$ & $6 \cdot 6,8 \cdot 8$ & $68 \cdot 0$ & $<0.001$ \\
\hline Cholesterol (mg/4184kJ) & $159 \cdot 0$ & 121,204 & $2 \cdot 0$ & $18 \overline{2 \cdot 0}$ & 145,218 & $3 \cdot 3$ & $132 \cdot 0$ & 101,167 & 0.3 & $165 \cdot 0$ & 127,209 & $2 \cdot 5$ & 0.008 \\
\hline Carbohydrate (\% energy) & $55 \cdot 4$ & $51 \cdot 5,59 \cdot 8$ & $18 \cdot 7$ & $52 \cdot 7$ & $49 \cdot 5,55 \cdot 7$ & $28 \cdot 4$ & $59 \cdot 4$ & $55 \cdot 6,62 \cdot 9$ & $7 \cdot 6$ & $55 \cdot 4$ & $51 \cdot 9,59 \cdot 2$ & $18 \cdot 2$ & $<0.001$ \\
\hline Dietary fibre $(\mathrm{g} / 4184 \mathrm{~kJ})$ & $6 \cdot 1$ & $5 \cdot 2,7 \cdot 3$ & $87 \cdot 3$ & $6 \cdot 2$ & $5 \cdot 4,7 \cdot 1$ & $91 \cdot 3$ & $5 \cdot 3$ & $4 \cdot 7,6 \cdot 2$ & $96 \cdot 2$ & $7 \cdot 7$ & $6 \cdot 9,9 \cdot 1$ & $62 \cdot 6$ & $<0.001$ \\
\hline $\mathrm{Na}$ (salt-equivalent) $(\mathrm{g} / 4184 \mathrm{~kJ}) \S$ & $5 \cdot 1$ & $4 \cdot 5,5 \cdot 8$ & $90 \cdot 7$ & $5 \cdot 3$ & $4 \cdot 7,5 \cdot 9$ & $96 \cdot 7$ & $4 \cdot 6$ & $4 \cdot 0,5 \cdot 2$ & $80 \cdot 3$ & $\overline{5 \cdot 6}$ & $5 \cdot 1,6 \cdot 4$ & $97 \cdot 0$ & $<0.001$ \\
\hline \multicolumn{14}{|l|}{ Nutrient with EAR } \\
\hline Protein (g/4184 kJ) & $33 \cdot 6$ & $30 \cdot 2,36 \cdot 4$ & $1 \cdot 3$ & 34.9 & $33 \cdot 1,37 \cdot 4$ & 0.0 & $29 \cdot 8$ & $27 \cdot 5,32 \cdot 0$ & $3 \cdot 5$ & $36 \cdot 3$ & $33 \cdot 6,39 \cdot 3$ & $0 \cdot 0$ & $<0.001$ \\
\hline Vitamin $A(\mu \mathrm{gRE} / 4184 \mathrm{~kJ}) \|$ & $263 \cdot 0$ & 195,371 & $41 \cdot 7$ & $280 \cdot 0$ & 219,363 & $34 \cdot 3$ & $202 \cdot 0$ & 150,281 & $63 \cdot 9$ & $3 \overline{83 \cdot 0}$ & 275,568 & $16 \cdot 8$ & $<0.001$ \\
\hline Vitamin $B_{1}(\mathrm{mg} / 4184 \mathrm{~kJ})$ & $0 \cdot 41$ & $0 \cdot 36,0.47$ & $76 \cdot 3$ & 0.44 & $0.39,0.48$ & $72 \cdot 3$ & 0.36 & $0 \cdot 32,0.41$ & $90 \cdot 8$ & 0.46 & $0.4,0.51$ & $58 \cdot 1$ & $<0.001$ \\
\hline Vitamin $B_{2}(\mathrm{mg} / 4184 \mathrm{~kJ})$ & 0.73 & $0.62,0.83$ & $11 \cdot 9$ & $0 \cdot 76$ & $0.68,0.86$ & $4 \cdot 0$ & 0.65 & $0.54,0.75$ & $24 \cdot 8$ & $\overline{0.79}$ & $0 \cdot 68,0.90$ & 4.9 & $<0.001$ \\
\hline Niacin (mgNE/4184 kJ) & $12 \cdot 3$ & $10 \cdot 9,13 \cdot 8$ & $0 \cdot 0$ & $12 \cdot 9$ & $11 \cdot 8,14 \cdot 1$ & $0 \cdot 0$ & $10 \cdot 7$ & $9 \cdot 6,11 \cdot 7$ & 0.0 & $1 \overline{4 \cdot 2}$ & $12 \cdot 8,15 \cdot 5$ & $0 \cdot 0$ & $<0.001$ \\
\hline Vitamin $B_{6}(\mathrm{mg} / 4184 \mathrm{~kJ})$ & 0.51 & $0.43,0.59$ & $97 \cdot 1$ & 0.52 & $0.47,0.59$ & $99 \cdot 1$ & 0.42 & $0.37,0.49$ & $99 \cdot 7$ & $0 . \overline{6} 2$ & $0.55,0.72$ & $88 \cdot 2$ & $<0.001$ \\
\hline Vitamin $B_{12}(\mu \mathrm{g} / 4184 \mathrm{~kJ})$ & $2 \cdot 8$ & $2 \cdot 1,3 \cdot 7$ & $3 \cdot 8$ & $2 \cdot 9$ & $2 \cdot 3,3 \cdot 7$ & $0 \cdot 2$ & $2 \cdot 2$ & $1 \cdot 6,2 \cdot 7$ & $10 \cdot 0$ & $\overline{3 \cdot 8}$ & $3 \cdot 1,4 \cdot 8$ & $0 \cdot 0$ & $<0.001$ \\
\hline Folate $(\mu \mathrm{g} / 4184 \mathrm{~kJ})$ & $149 \cdot 0$ & 126,178 & 84.9 & $151 \cdot 0$ & 132,171 & $88 \cdot 7$ & $130 \cdot 0$ & 110,152 & $95 \cdot 7$ & $18 \overline{7 \cdot 0}$ & 161,220 & $57 \cdot 1$ & $<0.001$ \\
\hline Vitamin C (mg/4184 kJ) & $53 \cdot 0$ & 41,70 & $38 \cdot 6$ & $51 \cdot 3$ & $40 \cdot 2,64 \cdot 6$ & $40 \cdot 9$ & $47 \cdot 8$ & $36 \cdot 0,67 \cdot 8$ & $50 \cdot 4$ & $67 \cdot 6$ & $53 \cdot 9,84 \cdot 6$ & $12 \cdot 3$ & $<0.001$ \\
\hline $\mathrm{Ca}(\mathrm{mg} / 4184 \mathrm{~kJ})$ & $287 \cdot 0$ & 231,348 & $42 \cdot 9$ & $305 \cdot 0$ & 259,365 & $29 \cdot 1$ & $250 \cdot 0$ & 190,303 & $64 \cdot 2$ & $3 \overline{06 \cdot 0}$ & 253,378 & 33.0 & $<0.001$ \\
\hline $\mathrm{Mg}(\mathrm{mg} / 4184 \mathrm{~kJ})$ & $118 \cdot 0$ & 104,134 & $70 \cdot 8$ & $120 \cdot 0$ & 112,134 & $68 \cdot 3$ & $103 \cdot 0$ & 93,115 & $91 \cdot 4$ & $\overline{138 \cdot 0}$ & 124,152 & $38 \cdot 4$ & $<0.001$ \\
\hline $\mathrm{Fe}(\mathrm{mg} / 4184 \mathrm{~kJ})$ & 3.5 & $3 \cdot 1,4 \cdot 1$ & $88 \cdot 1$ & $3 \cdot 7$ & $3 \cdot 3,4 \cdot 1$ & $85 \cdot 8$ & $3 \cdot 1$ & $2 \cdot 7,3 \cdot 4$ & $96 \cdot 2$ & $4 \cdot 2$ & $3 \cdot 7,4 \cdot 8$ & $77 \cdot 8$ & $<0.001$ \\
\hline $\mathrm{Zn}(\mathrm{mg} / 4184 \mathrm{~kJ})$ & $4 \cdot 0$ & $3 \cdot 6,4 \cdot 4$ & $63 \cdot 1$ & $4 \cdot 2$ & $3 \cdot 9,4 \cdot 5$ & $49 \cdot 7$ & $3 \cdot 6$ & $3 \cdot 3,3.9$ & $89 \cdot \overline{5}$ & $\overline{4 \cdot 3}$ & $4 \cdot 0,4 \cdot 6$ & $42 \cdot 9$ & $<0.001$ \\
\hline $\mathrm{Cu}(\mathrm{mg} / 4184 \mathrm{~kJ})$ & 0.54 & $0.49,0.60$ & $1 \cdot 5$ & 0.54 & $0.50,0.59$ & $0 \cdot 0$ & $0 \cdot 50$ & $0.46,0.55$ & $4 \cdot 0$ & $\overline{0.62}$ & $0.59,0.69$ & $0 \cdot 0$ & $<0.001$ \\
\hline \multicolumn{14}{|l|}{ Nutrient with Al } \\
\hline$n-6$ PUFA (g/4184kJ) & $1 \cdot 3$ & $1 \cdot 1,1 \cdot 5$ & - & $1 \cdot 4$ & $1 \cdot 2,1 \cdot 5$ & - & $1 \cdot 0$ & $0.9,1 \cdot 2$ & - & 1.5 & $1 \cdot 3,1 \cdot 7$ & - & $<0.001$ \\
\hline$n-3$ PUFA (g/4184kJ) & $6 \cdot 2$ & $5 \cdot 4,7 \cdot 1$ & - & $6 \cdot 7$ & $5 \cdot 9,7 \cdot 4$ & - & $5 \cdot 5$ & $4 \cdot 8,6 \cdot 2$ & - & $\overline{6 \cdot 4}$ & $5 \cdot 5,7 \cdot 3$ & - & $<0.001$ \\
\hline Vitamin D ( $\mu \mathrm{g} / 4184 \mathrm{~kJ})$ & $3 \cdot 0$ & $2 \cdot 2,4 \cdot 0$ & - & $\overline{3 \cdot 2}$ & $2 \cdot 5,4 \cdot 0$ & - & $2 \cdot 3$ & $1 \cdot 7,2 \cdot 9$ & - & $4 \cdot 3$ & $3 \cdot 5,5 \cdot 5$ & - & $<0.001$ \\
\hline Vitamin E $(\mathrm{mg} / 4184 \mathrm{~kJ})^{\star *}$ & $4 \cdot 2$ & $3 \cdot 6,4 \cdot 8$ & - & $4 \cdot \overline{4}$ & $3.9,4.9$ & - & $3 \cdot 7$ & $3 \cdot 2,4 \cdot 1$ & - & $\overline{4 \cdot 8}$ & $4 \cdot 1,5 \cdot 4$ & - & $<0.001$ \\
\hline Vitamin $\mathrm{K}(\mu \mathrm{g} / 4184 \mathrm{~kJ})$ & $106 \cdot 0$ & 77,146 & - & $120 \cdot 0$ & 92,149 & - & $75 \cdot 2$ & $56 \cdot 3,97 \cdot 8$ & - & $16 \overline{0 \cdot 0}$ & 121,215 & - & $<0.001$ \\
\hline Pantothenic acid (mg/4184 kJ) & $3 \cdot 1$ & $2 \cdot 7,3 \cdot 4$ & - & $3 \cdot 2$ & $2 \cdot 9,3 \cdot 5$ & - & $2 \cdot 7$ & $2 \cdot 4,3 \cdot 0$ & - & $3 \cdot 3$ & $3 \cdot 1,3 \cdot 7$ & - & $<0.001$ \\
\hline $\mathrm{K}(\mathrm{mg} / 4184 \mathrm{~kJ})$ & $1125 \cdot 0$ & 989,1289 & - & $1174 \cdot 0$ & 1062,1289 & - & 983.0 & 860,1109 & - & $131 \overline{9 \cdot 0}$ & 1170,1482 & - & $<0.001$ \\
\hline $\mathrm{P}(\mathrm{mg} / 4184 \mathrm{~kJ})$ & $513 \cdot 0$ & 452,573 & - & $535 \cdot 0$ & 497,586 & - & $445 \cdot 0$ & 400,496 & - & $558 \cdot 0$ & 514,625 & - & $<0.001$ \\
\hline $\mathrm{Mn}(\mathrm{mg} / 4184 \mathrm{~kJ})$ & $2 \cdot 0$ & $1 \cdot 7,2 \cdot 6$ & - & $2 \cdot 0$ & $1 \cdot 7,2 \cdot 4$ & - & $1 \cdot 9$ & $1 \cdot 6,2 \cdot 5$ & - & $2 \cdot 4$ & $2 \cdot 0,2 \cdot 9$ & - & $<0.001$ \\
\hline
\end{tabular}

DHQ, diet history questionnaire; DRI, Dietary Reference Intakes; IQR, interquartile range; DG, Tentative Dietary Goal for Preventing Lifestyle-related Disease; EAR, Estimated Average Requirement; Al, Adequate Intake; RE, retinol equivalents; NE, niacin equivalents.

*Intakes of energy and all nutrients were significantly different between clusters $(P=0.014$ for energy and $P<0.001$ for all nutrients; Kruskal-Wallis test). The highest median values are underlined.

tPercentage of participants with values outside the DG or below the EAR. Each energy-adjusted nutrient intake (unit/4184 kJ) estimated by the DHQ was compared with each corresponding energy-adjusted DRI value (unit/4184 kJ), using the cut-point method according to the Japanese DRI, 2010 ${ }^{(10)}$. Nutrients with an Al were not examined.

$\ddagger \chi^{2}$ test was used to examine the difference of prevalence of inadequacy across the three dietary patterns.

SConsidering the convenience of the use, the DG of $\mathrm{Na}$ is expressed as salt-equivalent [salt $(\mathrm{g})=58 \cdot 5 / 23 \times \mathrm{Na}(\mathrm{g})]^{(10)}$

II $\mu \mathrm{gRE}=$ retinol $(\mu \mathrm{g})+\beta$-carotene $(\mu \mathrm{g}) \times 1 / 12+\alpha$-carotene $(\mu \mathrm{g}) \times 1 / 24+\beta$-cryptoxanthin $(\mu \mathrm{g}) \times 1 / 24+$ other provitamin $\mathrm{A}$ carotenoids $(\mu \mathrm{g}) \times 1 / 24^{(10)}$

- Niacin equivalents were computed as niacin $(\mathrm{mg})+$ protein $(\mathrm{mg}) / 6000(10)$

${ }^{* \star}$ Computation was made on $\alpha$-tocopherol. Vitamin $\mathrm{E}$ other than $\alpha$-tocopherol was not included. 
'rice, fish and vegetables' pattern had the lowest prevalence of inadequacy for the intake of many nutrients compared with participants with the other dietary patterns but, owing to higher intake of pickled vegetables, salty fish and salt-containing seasonings, they had a significantly higher prevalence of inadequacy for sodium (97.0\%; Table 4). The participants with the 'meat and eggs' pattern had the highest prevalence of inadequacy for total fat and SFA $v$. the other dietary patterns, whereas those with the 'wheat products' pattern had the highest prevalence of inadequacy for almost all nutrients except for carbohydrates. The food items of the 'rice, fish and vegetables', 'meat and eggs' and 'wheat products' patterns identified by cluster analysis in the present study were comparable with those of 'health-conscious', 'processed' and 'confectionery' patterns, respectively, identified by principal component analysis among pregnant women from South-West England ${ }^{(29)}$. The nutrients related to each dietary pattern were also similar between the patterns in the present and the previous study ${ }^{(29)}$. Similarity was also seen for the above-mentioned three dietary patterns in the present study with 'healthy', 'traditional meat' and 'fast foods' patterns, respectively, in pregnant Finnish women ${ }^{(31)}$. These results suggest that the dietary pattern high in vegetables, fruit, pulses, fish and dairy products is associated with high intake of protein and several key vitamins and minerals regardless of the analytic methods for identifying dietary patterns.

Several previous studies have reported that the 'healthy' or 'health-conscious' pattern in pregnant women is positively associated with higher educational levels, owneroccupied housing, fewer financial difficulties, older age and less smoking ${ }^{(30-32)}$. In contrast, the 'fast food' dietary pattern shows a positive association with smoking ${ }^{(31)}$. Consistent with the previous studies ${ }^{(30-32)}$, the participants with the 'rice, fish and vegetables' pattern had higher own and partner education levels, used more dietary supplements and smoked less, whereas those with the 'wheat products' pattern had the opposite characteristics (Table 3). These results suggest that participants with higher sociodemographic status and favourable healthrelated characteristics tend to choose healthy foods.

Although the assessment of nutritional adequacy was focused on the dietary pattern, we should also give attention to specific fundamental nutrients during pregnancy such as folate, $\mathrm{B}$ vitamins, iron and zinc. More than half of all participants were at risk of inadequate intake of several nutrients such as dietary fibre, vitamin $\mathrm{B}_{1}$, vitamin $\mathrm{B}_{6}$, folate, magnesium, iron, zinc, total fat, SFA and sodium (Table 4). Similar results have been observed in other studies focusing on nutrient intake level conducted in Portugal ${ }^{(22)}$, South-East Asia ${ }^{(3)}$, rural China $^{(4)}$ and Japan ${ }^{(5,34)}$, but not in Greece ${ }^{(6)}$. Dietary education is therefore needed, not only for specified participants with an unfavourable dietary pattern but for all pregnant women.
In the present study, nutritional adequacy was examined using the DRI for Japanese as a temporal gold standard. The basic concept of the Japanese DRI is similar to the US and Canadian DRI ${ }^{(19)}$, especially for the definition of each DRI such as EAR, RDA, AI, Tolerable Upper Intake Level and EER (Appendix 1). However, some nutrients were set for different DRI between the two (US/Canadian and Japanese) recommendations. In addition, the DG was defined for the prevention of chronic disease in the Japanese DRI instead of the AMDR defined by the US and Canadian DRI, which is the most remarkable difference between the two DRI. Therefore, data on nutritional adequacy with different nutrient recommendations should be compared cautiously.

Several limitations of the present study warrant mention. First, the response rate for the 627 women living in Neyagawa City was only $17 \cdot 2 \%$, whereas that for the remaining 375 living in other municipalities could not be calculated because of the unavailable exact number of eligible participants. Moreover, the survey area was restricted to a single prefecture in Japan. Therefore, the participants were likely not representative of pregnant Japanese women. Second, although we used a validated dietary assessment questionnaire, its ability to estimate dietary intake remains a serious concern. In addition, we might not capture the within-person variation of intake because of only one measurement of diet. Incompleteness of assessment could not be ruled out. Therefore, the results should be interpreted with caution. Furthermore, misreporting of self-reported food intake is a source of measurement error, particularly under-reporting rather than over-reporting ${ }^{(35)}$. To minimize the influence of underreporting ${ }^{(17)}$, we used energy-adjusted values. Third, we did not include nutrient intake from dietary supplements in the analysis because of the lack of a reliable composition table for such items in Japan. Fourth, because body weight before pregnancy was not obtained, we could not evaluate dietary quality from the standpoint of energy requirement during pregnancy by BMI or body weight gain. Fifth, the study included participants with various gestational ages (5-39 weeks). However, some previous longitudinal studies reported a relative consistency of dietary habits throughout the pregnancy period ${ }^{(33,36)}$. Sixth, the number of nutrients that did not meet the DRI was counted equally to evaluate the overall inadequacy of nutrient intake of each dietary pattern. Although the contribution to overall nutritional quality might be different across nutrients, the evidence to determine the weighting coefficients of each nutrient was insufficient at the present time. The results should therefore be interpreted very cautiously. Finally, because the reliability of the DRI for individual nutrients is dependent on the state of the science for each nutrient ${ }^{(10)}$, misclassification of participants by nutrients might therefore have been unavoidable.

In conclusion, we examined the nutritional adequacy of dietary patterns identified by cluster analysis in pregnant 
Japanese women. A diet high in rice, vegetables, potatoes, pulses, fruit, mushrooms, seaweed, fish, shellfish and miso soup showed a better profile of overall nutrient intake. Further studies in various populations are required to confirm these results.

\section{Acknowledgements}

The present study was supported by a Grant-in-aid (13770206 and 16790351) for Scientific Research from the Ministry of Education, Culture, Sports, Science and Technology; Health and Labour Sciences Research grants; Research on Allergic Disease and Immunology from the Ministry of Health, Labour and Welfare; and a Grant-in-aid for JSPS Fellows (21-3370) from the Japan Society for the Promotion of Science. None of the authors had any personal or financial conflict of interest to declare. H.O. conducted the statistical analyses and wrote the manuscript. Y.M. and S.S. contributed to the planning of the OMCHS and data collection and assisted in manuscript preparation. K.T. contributed to data collection. K.M. assisted in manuscript preparation. Y.H. supervised the design and execution of the OMCHS. All authors contributed to and approved the final manuscript. The authors thank the Neyagawa City Government, Hirakata City Government, Katano City Government, Shijonawate City Government, Kaizuka City Government, Takaishi City Government, Hannan City Government, Neyagawa City Medical Association, Hirakata City Medical Association and Kadoma City Medical Association for their valuable support.

\section{References}

1. Harding JE (2001) The nutritional basis of the fetal origins of adult disease. Int J Epidemiol 30, 15-23.

2. Barker DJ (1997) Maternal nutrition, fetal nutrition, and disease in later life. Nutrition 13, 807-813.

3. Seshadri S (2001) Prevalence of micronutrient deficiency particularly of iron, zinc and folic acid in pregnant women in South East Asia. Br J Nutr 85, S87-S92.

4. Cheng Y, Dibley MJ, Zhang X et al. (2009) Assessment of dietary intake among pregnant women in a rural area of western China. BMC Public Health 9, 222.

5. Takimoto H, Mito N, Umegaki K et al. (2007) Relationship between dietary folate intakes, maternal plasma total homocysteine and B-vitamins during pregnancy and fetal growth in Japan. Eur J Nutr 46, 300-306.

6. Petrakos G, Panagopoulos P, Koutras I et al. (2006) A comparison of the dietary and total intake of micronutrients in a group of pregnant Greek women with the dietary reference intakes. Eur J Obstet Gynecol Reprod Biol 127, 166-171.

7. Tucker KL, Dallal GE \& Rush D (1992) Dietary patterns of elderly Boston-area residents defined by cluster analysis. J Am Diet Assoc 92, 1487-1491.

8. Newby PK \& Tucker KL (2004) Empirically derived eating patterns using factor or cluster analysis: a review. Nutr Rev 62, 177-203.

9. Moeller SM, Reedy J, Millen AE et al. (2007) Dietary patterns: challenges and opportunities in dietary patterns research an Experimental Biology workshop, April 1, 2006. J Am Diet Assoc 107, 1233-1239.
10. Ministry of Health, Labor, and Welfare of Japan (2009) Dietary reference intakes for Japanese. http://www. mhlw.go.jp/shingi/2009/05/s0529-4.html (accessed September 2009).

11. Miyake Y, Miyamoto S, Ohya Y et al. (2004) Relationship between active and passive smoking and total serum IgE levels in Japanese women: baseline data from the Osaka Maternal and Child Health Study. Int Arch Allergy Immunol 135, 221-228.

12. Tanaka K, Miyake Y, Sasaki S et al. (2005) Active and passive smoking and tooth loss in Japanese women: baseline data from the Osaka Maternal and Child Health Study. Ann Epidemiol 15, 358-364.

13. Sasaki S, Yanagibori R \& Amano K (1998) Validity of a selfadministered diet history questionnaire for assessment of sodium and potassium: comparison with single 24-hour urinary excretion. Jpn Circ J 62, 431-435.

14. Sasaki S, Ushio F, Amano K et al. (2000) Serum biomarkerbased validation of a self-administered diet history questionnaire for Japanese subjects. J Nutr Sci Vitaminol 46, 285-296.

15. Sasaki S, Yanagibori R \& Amano K (1998) Self-administered diet history questionnaire developed for health education: a relative validation of the test-version by comparison with 3-day diet record in women. J Epidemiol 8, 203-215.

16. Science and Technology Agency (2005) Standard Tables of Food Composition in Japan, 5th revised and enlarged ed. Tokyo: Printing Bureau of the Ministry of Finance.

17. Murakami K, Sasaki S, Takahashi Y et al. (2008) Misreporting of dietary energy, protein, potassium and sodium in relation to body mass index in young Japanese women. Eur J Clin Nutr 62, 111-118.

18. Willett WC, Howe GR \& Kushi LH (1997) Adjustment for total energy intake in epidemiologic studies. Am J Clin Nutr 65, 4 Suppl., 1220S-1228S.

19. Institute of Medicine, Food and Nutrition Board (2000) Dietary Reference Intakes: Applications in Dietary Assessment. Washington, DC: National Academy Press.

20. Institute of Medicine, Food and Nutrition Board (2001) Dietary Reference Intake: for Vitamin A, Vitamin K, Arsenic, Boron, Chromium, Copper, Iodine, Iron, Manganese, Molybdenum, Nickel, Silicon, Vanadium, and Zinc. Washington, DC: National Academy Press.

21. Cockell KA, Miller DC \& Lowell H (2009) Application of the dietary reference intakes in developing a recommendation for pregnancy iron supplements in Canada. Am J Clin Nutr 90, 1023-1028.

22. Pinto E, Barros H \& dos Santos Silva I (2009) Dietary intake and nutritional adequacy prior to conception and during pregnancy: a follow-up study in the north of Portugal. Public Health Nutr 12, 922-931.

23. Ministry of Health and Welfare of Japan (1999) Recommended Dietary Allowance for Japanese: Dietary Reference Intakes, 6th revised ed. Tokyo: Ministry of Health and Welfare.

24. Sasaki S (2008) Dietary Reference Intakes (DRIs) in Japan. Asia Pac J Clin Nutr 17, Suppl. 2, 420-444.

25. Ministry of Health, Labor, and Welfare of Japan (2008) The National Health and Nutrition Survey in Japan, 2005. Tokyo: Ministry of Health, Labor and Welfare.

26. SAS Institute (2004) SAS/STAT 9.1 User's Guide, pp. 1379-1426. Cary, NC: SAS Institute Inc.

27. Serra-Majem L, Bes-Rastrollo M, Roman-Vinas B et al. (2009) Dietary patterns and nutritional adequacy in a Mediterranean country. Br J Nutr 101, Suppl. 2, S21-S28.

28. Beaudry M, Galibois I \& Chaumette P (1998) Dietary patterns of adults in Québec and their nutritional adequacy. Can J Public Health 89, 347-351. 
29. Northstone K, Emmett PM \& Rogers I (2008) Dietary patterns in pregnancy and associations with nutrient intakes. Br J Nutr 99, 406-415.

30. Northstone K, Emmett P \& Rogers I (2008) Dietary patterns in pregnancy and associations with socio-demographic and lifestyle factors. Eur J Clin Nutr 62, 471-479.

31. Arkkola T, Uusitalo U, Kronberg-Kippila C et al. (2008) Seven distinct dietary patterns identified among pregnant Finnish women - associations with nutrient intake and sociodemographic factors. Public Health Nutr 11, 176-182.

32. Brantsaeter AL, Haugen M, Samuelsen SO et al. (2009) A dietary pattern characterized by high intake of vegetables, fruits, and vegetable oils is associated with reduced risk of preeclampsia in nulliparous pregnant Norwegian women. J Nutr 139, 1162-1168.

33. Cuco G, Fernandez-Ballart J, Sala J et al. (2006) Dietary patterns and associated lifestyles in preconception, pregnancy and postpartum. Eur J Clin Nutr 60, 364-371.

34. Mito N, Takimoto H, Umegaki K et al. (2007) Folate intakes and folate biomarker profiles of pregnant Japanese women in the first trimester. Eur J Clin Nutr 61, 83-90.

35. Livingstone MB \& Black AE (2002) Markers of the validity of reported energy intake. J Nutr 133, Suppl. 3, 895S-920S.

36. Crozier SR, Robinson SM, Godfrey KM et al. (2009) Women's dietary patterns change little from before to during pregnancy. J Nutr 139, 1956-1963.

\section{Appendix 1}

\section{Brief comparison of DRI between the USA/Canada and Japan*}

\begin{tabular}{|c|c|c|}
\hline DRI definitionst & USA and Canada & Japan \\
\hline \multicolumn{3}{|l|}{ EAR } \\
\hline $\begin{array}{l}\text { The average daily nutrient intake level estimated } \\
\text { to meet the requirements of half the healthy } \\
\text { individuals in a particular life stage and gender } \\
\text { group }\end{array}$ & $\begin{array}{l}\text { Carbohydrate, protein, } \\
\text { indispensable amino acids, } \\
\text { vitamin } A \text {, vitamin } E \text {, thiamin, } \\
\text { riboflavin, niacin, vitamin } B_{6}, \\
\text { vitamin } B_{12} \text {, folate, vitamin } \mathrm{C}, \\
\mathrm{Mg}, \mathrm{Fe}, \mathrm{Zn}, \mathrm{Cu} \text {, iodine, Mo, } \mathrm{P}, \mathrm{Se}\end{array}$ & $\begin{array}{l}\text { Protein, indispensable amino acids, } \\
\text { vitamin } A \text {, vitamin } B_{1} \text {, vitamin } B_{2} \text {, } \\
\text { niacin, vitamin } B_{6}, \text { vitamin } B_{12} \text {, folate, } \\
\text { vitamin } \mathrm{C}, \mathrm{Na}, \mathrm{Ca}, \mathrm{Mg}, \mathrm{Fe}, \mathrm{Zn}, \mathrm{Cu}, \\
\text { iodine, Mo, } \mathrm{Se}, \underline{\mathrm{Cr}}\end{array}$ \\
\hline \multicolumn{3}{|c|}{ 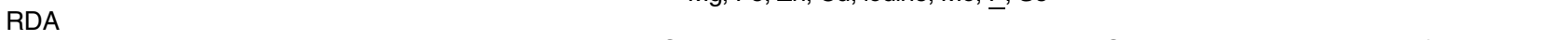 } \\
\hline $\begin{array}{l}\text { The average daily dietary nutrient intake level } \\
\text { sufficient to meet the nutrient requirement of nearly } \\
\text { all }(97-98 \%) \text { healthy individuals in a particular life } \\
\text { stage and gender group }\end{array}$ & Same as the above & Same as the above except for $\mathrm{Na}$ \\
\hline \multicolumn{3}{|l|}{ Al } \\
\hline $\begin{array}{l}\text { The recommended average daily nutrient intake } \\
\text { level based on observed or experimentally } \\
\text { determined approximations or estimates of nutrient } \\
\text { intake by a group (or groups) of apparently healthy } \\
\text { people that are assumed to be adequate; used } \\
\text { when an RDA cannot be determined }\end{array}$ & $\begin{array}{l}\text { Total fibre, linoleic acid, } \alpha \text {-linolenic } \\
\text { acid, vitamin } \mathrm{D} \text {, vitamin } \mathrm{K}, \\
\text { pantothenic acid, cholinet, } \\
\text { biotin, } \mathrm{Ca}, \mathrm{Cr}, \mathrm{Ft}, \overline{\mathrm{Mn}, \mathrm{K}}, \underline{\mathrm{Na}}, \\
\text { Clt, total watert }\end{array}$ & $\begin{array}{l}n-6 \text { PUFA, } n-3 \text { PUFA, vitamin D, vitamin } \\
\text { E, vitamin K, pantothenic acid, biotin, } \\
\overline{\mathrm{K}}, \underline{\mathrm{P}}, \mathrm{Mn}\end{array}$ \\
\hline \multicolumn{3}{|l|}{ UL } \\
\hline $\begin{array}{l}\text { The highest average daily nutrient intake level } \\
\text { likely to pose no risk of adverse health effects to } \\
\text { almost all individuals in the general population. As } \\
\text { the intake increases above the UL, the potential } \\
\text { risk of adverse effects may increase } \\
\text { AMDR }\end{array}$ & $\begin{array}{l}\text { Vitamin } \mathrm{A} \text {, vitamin } \mathrm{D} \text {, vitamin } \mathrm{E}, \\
\text { niacin, vitamin } \mathrm{B}_{6}, \text { folate, } \\
\text { cholinet, vitamin } \mathrm{C}, \mathrm{B}+\mathrm{Ca}, \\
\overline{\mathrm{Cu}, \mathrm{Ft}} \text {, iodine, } \mathrm{Fe}, \overline{\mathrm{Mg}}, \mathrm{Mn}, \mathrm{Mo}, \\
\text { Nit, } \overline{\mathrm{P}}, \mathrm{Se}, \underline{\mathrm{V}}, \mathrm{Zn}, \mathrm{Na}, \underline{\mathrm{Cl}}\end{array}$ & 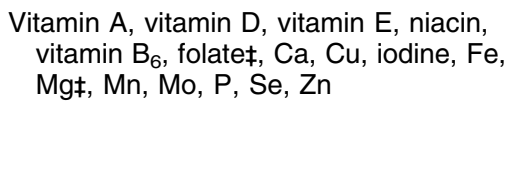 \\
\hline $\begin{array}{l}\text { Range of intake for a particular energy source that } \\
\text { is associated with reduced risk of chronic disease } \\
\text { (e.g. CHD, obesity, diabetes and/or cancer) while } \\
\text { providing adequate intake of essential nutrients }\end{array}$ & $\frac{\text { Carbohydrate, }}{n-6 \text { pUFA }}, \frac{n-3 \text { PUFA }}{n-1 \text { total fat, }}$ & - \\
\hline \multicolumn{3}{|l|}{ DG } \\
\hline $\begin{array}{l}\text { The average daily nutrient intake level (or ranges) } \\
\text { that Japanese should currently aim to consume } \\
\text { primarily to prevent chronic diseases (e.g. CVD } \\
\text { (hypertension, hyperlipidaemia, stroke, and } \\
\text { myocardial infarction) and cancer (especially, } \\
\text { stomach cancer)) }\end{array}$ & - & 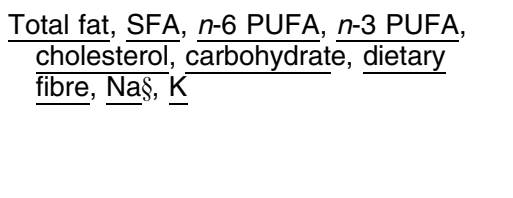 \\
\hline \multicolumn{3}{|r|}{-} \\
\hline $\begin{array}{l}\text { The average dietary energy intake that is } \\
\text { predicted to maintain energy balance in a healthy } \\
\text { adult of a defined age, gender, weight, height and } \\
\text { level of physical activity }\end{array}$ & $\begin{array}{l}\text { Energy } \\
\text { PAL (four levels): sedentary } \\
\quad(1 \cdot 00-1 \cdot 39), \text { low active } \\
\quad(1 \cdot 40-1 \cdot 59), \text { active }(1 \cdot 60-1 \cdot 89) \\
\quad \text { and very active }(1 \cdot 90-2 \cdot 50)\end{array}$ & $\begin{array}{l}\text { Energy } \\
\text { PAL (three levels): low }(1 \cdot 40-1 \cdot 60) \text {, } \\
\quad \text { moderate }(1 \cdot 60-1 \cdot 90) \text { and high } \\
(1 \cdot 90-2 \cdot 20)\end{array}$ \\
\hline
\end{tabular}

DRI, Dietary Reference Intake; EAR, Estimated Average Requirement; Al, Adequate Intake; UL, Tolerable Upper Intake Level; AMDR, Acceptable Macronutrient Distribution Range; DG, Tentative Dietary Goal for Preventing Lifestyle-related Disease; EER, estimated energy requirement; PAL, physical activity level. ${ }^{*}$ Nutrients set for DRI presented in this table are for $\geq 1$-year-olds ${ }^{(10,19)}$.

+Nutrients set only for the US and Canadian DRI; nutrients set for different DRI between the USA and Canada and Japan are underlined.

$\mp U L$ for folate and $\mathrm{Mg}$ were defined as intake from other than normal foods.

$\S$ Considering the convenience of the use, the values are expressed as salt-equivalent [salt $(\mathrm{g})=58 \cdot 5 / 23 \times \mathrm{Na}(\mathrm{g})]$.

The basic concept is similar between Japanese and the US and Canadian DRI, especially for definition of each dietary reference index such as EAR, RDA, Al, UL and EER. However, AMDR was not defined in the Japanese DRI. Instead of AMDR, DG was defined for the prevention of chronic disease. 
Appendix 2

DRI for pregnant Japanese women aged 18-49 years

\begin{tabular}{|c|c|c|c|c|c|}
\hline \multirow[b]{3}{*}{ Nutrient } & \multicolumn{5}{|c|}{ Reference values for pregnant women* } \\
\hline & \multicolumn{2}{|c|}{ Reference values for non-pregnant women } & \multicolumn{3}{|c|}{ Increment during pregnancy $\dagger$} \\
\hline & 18-29 years & $30-49$ years & $\begin{array}{c}\text { Early-stage } \\
(<16 \text { weeks })\end{array}$ & $\begin{array}{c}\text { Mid-stage } \\
\text { (16-27 weeks) }\end{array}$ & $\begin{array}{l}\text { Late-stage } \\
(\geq 28 \text { weeks) }\end{array}$ \\
\hline \multicolumn{6}{|l|}{$\operatorname{EER}(\mathrm{kJ} / \mathrm{d}) \ddagger$} \\
\hline Low (PAL: 1·40-1·60) & $7113(1700)$ & $7322(1750)$ & $+209(+50)$ & $+1046(+250)$ & $+1883(+450)$ \\
\hline Moderate (PAL: $1 \cdot 60-1 \cdot 90)$ & 8159 (1950) & 8368 (2000) & $+209(+50)$ & $+1046(+250)$ & $+1883(+450)$ \\
\hline High (PAL: 1·90-2·20) & 9414 (2250) & $9623(2300)$ & $+209(+50)$ & $+1046(+250)$ & $+1883(+450)$ \\
\hline \multicolumn{6}{|l|}{ Nutrient with DG } \\
\hline Total fat (\% energy) & $20-30$ & $20-25$ & - & - & - \\
\hline SFA (\% energy) & $4 \cdot 5-7 \cdot 0$ & $4 \cdot 5-7 \cdot 0$ & - & - & - \\
\hline Cholesterol (mg/d) & $<600$ & $<600$ & - & - & - \\
\hline Carbohydrate (\% energy) & $50-70$ & $50-70$ & - & - & - \\
\hline Dietary fibre $(\mathrm{g} / \mathrm{d})$ & $\geq 17$ & $\geq 17$ & - & - & - \\
\hline $\mathrm{Na}$ (salt-equivalent; g/d) & $<7 \cdot 5$ & $<7 \cdot 5$ & - & - & - \\
\hline \multicolumn{6}{|l|}{ Nutrient with EAR } \\
\hline Protein $(\mathrm{g} / \mathrm{d})$ & $\geq 40$ & $\geq 40$ & +0 & +5 & +20 \\
\hline Vitamin A $(\mu \mathrm{gRE} / \mathrm{d}) \S$ & $\geq 450$ & $\geq 500$ & +0 & +0 & +60 \\
\hline Vitamin $B_{1}(\mathrm{mg} / \mathrm{d})$ & $\geq 0.9$ & $\geq 0.9$ & +0 & $+0 \cdot 1$ & $+0 \cdot 2$ \\
\hline Vitamin $B_{2}(m g / d)$ & $\geq 1 \cdot 0$ & $\geq 1 \cdot 0$ & +0 & $+0 \cdot 1$ & $+0 \cdot 2$ \\
\hline Niacin (mgNE/d)\| & $\geq 9$ & $\geq 10$ & +0 & +0 & +0 \\
\hline Vitamin $B_{6}(\mathrm{mg} / \mathrm{d})$ & $\geq 1 \cdot 0$ & $\geq 1 \cdot 0$ & $+0 \cdot 7$ & $+0 \cdot 7$ & $+0 \cdot 7$ \\
\hline Vitamin $B_{12}(\mu \mathrm{g} / \mathrm{d})$ & $\geq 2 \cdot 0$ & $\geq 2 \cdot 0$ & $+0 \cdot 3$ & $+0 \cdot 3$ & $+0 \cdot 3$ \\
\hline Folate $(\mu \mathrm{g} / \mathrm{d})$ & $\geq 200$ & $\geq 200$ & +200 & +200 & +200 \\
\hline Vitamin C (mg/d) & $\geq 85$ & $\geq 85$ & +10 & +10 & +10 \\
\hline $\mathrm{Ca}(\mathrm{mg} / \mathrm{d})$ & $\geq 550$ & $\geq 550$ & +0 & +0 & +0 \\
\hline $\mathrm{Mg}(\mathrm{mg} / \mathrm{d})$ & $\geq 230$ & $\geq 240$ & +30 & +30 & +30 \\
\hline $\mathrm{Fe}(\mathrm{mg} / \mathrm{d})$ & $\geq 5 \cdot 0$ & $\geq 5 \cdot 5$ & +2 & $+12 \cdot 5$ & $+12 \cdot 5$ \\
\hline $\mathrm{Zn}(\mathrm{mg} / \mathrm{d})$ & $\geq 7$ & $\geq 8$ & +1 & +1 & +1 \\
\hline $\mathrm{Cu}(\mathrm{mg} / \mathrm{d})$ & $\geq 0 \cdot 6$ & $\geq 0 \cdot 6$ & $+0 \cdot 1$ & $+0 \cdot 1$ & $+0 \cdot 1$ \\
\hline \multicolumn{6}{|l|}{ Nutrient with Al } \\
\hline$n-6$ PUFA (g/d) & $\geq 9$ & $\geq 9$ & +1 & +1 & +1 \\
\hline$n-3$ PUFA (g/d) & - & - & $\geq 1 \cdot 9$ & $\geq 1 \cdot 9$ & $\geq 1.9$ \\
\hline Vitamin D $(\mu \mathrm{g} / \mathrm{d})$ & $\geq 5 \cdot 5$ & $\geq 5 \cdot 5$ & $+1 \cdot 5$ & $+1 \cdot 5$ & $+1 \cdot 5$ \\
\hline Vitamin E (mg/d) & $\geq 6 \cdot 5$ & $\geq 6 \cdot 5$ & +0 & +0 & +0 \\
\hline Vitamin K $(\mu \mathrm{g} / \mathrm{d})$ & $\geq 60$ & $\geq 65$ & +0 & +0 & +0 \\
\hline Pantothenic acid (mg/d) & $\geq 5$ & $\geq 5$ & +1 & +1 & +1 \\
\hline $\mathrm{K}(\mathrm{mg} / \mathrm{d})$ & $\geq 2000$ & $\geq 2000$ & +0 & +0 & +0 \\
\hline$P(\mathrm{mg} / \mathrm{d})$ & $\geq 900$ & $\geq 900$ & +0 & +0 & +0 \\
\hline$M n(m g / d)$ & $\geq 3 \cdot 5$ & $\geq 3 \cdot 5$ & +0 & +0 & +0 \\
\hline
\end{tabular}

DRI, Dietary Reference Intake; EER, estimated energy requirement; PAL, physical activity level; DG, Tentative Dietary Goal for Preventing Lifestyle-related Disease; EAR, Estimated Average Requirement; RE, retinol equivalent; NE, niacin equivalent; Al, Adequate Intake.

*The reference values of each nutrient for pregnant women are calculated by adding the increment of each nutrient during pregnancy to the corresponding reference values for non-pregnant women.

tGestational age was classified into three categories according to the DRI for Japanese ${ }^{(10)}$.

$\ddagger$ The values in parentheses are given in $\mathrm{kcal} .1 \mathrm{kcal}=4 \cdot 184 \mathrm{~kJ}$.

$\S 1 \mu \mathrm{gRE}=$ retinol $(\mu \mathrm{g})+\beta$-carotene $(\mu \mathrm{g}) \times 1 / 12+\alpha$-carotene $(\mu \mathrm{g}) \times 1 / 24+\beta$-cryptoxanthin $(\mu \mathrm{g}) \times 1 / 24+$ other provitamin $\mathrm{A}$ carotenoids $(\mu \mathrm{g}) \times 1 / 24^{(10)}$.

IINiacin equivalents were computed as niacin $(\mathrm{mg})+$ protein $(\mathrm{mg}) / 6000^{(10)}$. 